\title{
Corruption and Illegal Payments in Greece
}

\author{
Giorgos P. Zacharakis \\ Dept. of Sport of Sports Organization and Management, University of Peloponnese \\ T.K 23100, Sparta, Greece \\ Tel: 30-2731089658Ｅ-mail: zacharakisgeo@yahoo.gr \\ Panagiota I. Antonopoulou \\ Dept. of Sport of Sports Organization and Management, University of Peloponnese \\ T.K 23100, Sparta, Greece \\ Tel: 30-2731089681Ｅ-mail: pantonop@uop.gr
}

Antonios K. Travlos

Dept. of Sport of Sports Organization and Management, University of Peloponnese

T.K 23100, Sparta, Greece

Tel: 30-2731089672Ｅ-mail: atravlos@uop.gr

George S. Kipreos (Corresponding author)

Dept. of Sport of Sports Organization and Management, University of Peloponnese

T.K 23100, Sparta, Greece

Tel: 30-2731089668Ｅ-mail: kipreos@uop.gr

Received: March 26, 2017 Accepted: May 5, 2017 Published: May 9, 2017

doi:10.5296/jpmr.v3i1.11191 URL: https://doi.org/10.5296/jpmr.v3i1.11191

\begin{abstract}
The phenomenon of corruption is global and extends in many areas of the public sector. However, in Greece it appears to be socially acceptable since in the case of illegal benefits and pensions, the corruption of the public officials takes place with the collaboration of the
\end{abstract}


citizens who receive such pensions and allowances. It should be noted that in Greece the phenomenon has not been fully recorded since the only information available can be derived from the Press due to the publicity that such cases take and because of the large sums of money involved and the great damage they cause to the public sector. The fact is that this phenomenon is an important proof for the social fostering of corruption and that it is motivated by the pursuit of illicit enrichment both by the public officials and the citizens.

Keywords: Corruption, public sector, illegal activity, benefits, pensions.

\section{Introduction}

Corruption is a global problem affecting both economic and human development. The word corruption is derived from the Latin word "corruptus", meaning rot or decay. Also, it defines the degenerative process of the standards and values that govern our society (Bardhan, 1997; Osipian, 2010; Hwagn \& Lim, 2013).

According to this concept, corruption is an effect of the relations between the state and the people who do not act in favor of the collective welfare. Moreover, corruption is the social behavior that is determined by a change that can be understood under three forms: a) violation of the rule of law, b) violation of the economic system, c) violation of the political regime (Rose-Ackerman, 2013).

In the first case there is a violation of the legal rules, while the second case concerns the institution of the economy, namely the corruption concerns changes in the allocation of resources and price distortions. Finally, in the third case corruption concerns the decline of the political system (Mo, 2001).

Corruption in modern societies appears as a trend, which is included among the ways to influence government action and acts like violence and propaganda (Heidenheimer \& Johnston, 2009). In the case of Greece, however, the official state does not perceive that corruption is a problem with political dimensions characterized by a lack of transparency and democratic deficit that stems from its ranks. Instead, corruption is treated as a phenomenon with exclusively criminal dimensions, excluding itself from its maintenance and reproduction (Lagarias, 2016).

In reality, corruption in Greece is the result of the political system and its functioning which allows the creation of corruption opportunities regardless if it spreads to all areas such as sports (Antonopoulou, 2008). This gap is exploited by citizens who contribute to the perpetuation of the phenomenon. Moreover, the wrong approach and analysis of corruption in Greece leads in turn to wrong solutions and actions allowing its preservation (Lagarias, 2016).

\section{Literature Review}

\subsection{Forms of Corruption}

In developing countries, corruption may be due to the existence of extreme poverty, according to the opinions of those who have suffered from corrupt oligarchic regimes that 
audaciously spend the natural resources of their countries recklessly and aimlessly. In developed countries, phenomena such as professional uncertainty and the decline in corporate trust are triggers that create opportunities for corruption (Bardhan, 1997).

At this point it is necessary to make a distinction between a) serious corruption cases involving decision makers at the level of national government - ministers, senior players, etc. and b) minor corruption cases in which bureaucrats whose job is to plan and execute public policies, seek to maximize their personal goals through corruption at the expense of the public (Morris, 2011).

It is thought that bureaucratic corruption is directly related to the scope and extent of government intervention in the private exchange (i.e. the markets). Effective control of corruption should be based on a modification of the existing rules in order to change the structures of incentives to limit the state's ability to intervene in the private exchange and the creation of artificial shortages (Acemoglu \& Verdier, 2000).

With regard to the serious cases of corruption, these focus on the acquisition of large amounts, while the minor corruption cases mainly concern small amounts of money. However, both forms of corruption are harmful to society. More specifically, in the case of serious corruption cases, tax evasion is one of the most popular forms. Mostly this is practiced by state officials and politicians that lead to the accumulation of black money which in turn damages the morale of the people (Morris, 2011).

The damage caused by minor corruption cases has another impact. For example, an entrepreneur who wants to secure a lucrative import or production license may bribe an official at the Ministry of Commerce, in order to: 1) obtain authorization and 2) to ensure that the agency will protect the new monopoly position by not granting additional licenses for entrepreneurs from the region in which the entrepreneur operates. In return, for the provision of opportunities to the entrepreneur to earn above normal profits, civil servants in the Ministry of Commerce also earn extra income and the importer that obtains the license wins an above normal return on investment, while society loses.

\subsection{Measures and Policies on Transparency}

Despite the fact that corruption is a common practice in many countries, it would be a mistake to consider the phenomenon itself as part of the manners and customs (Tanzi, 1998; Treisman, 2000; Montinola \& Jackman, 2002; Seligson, 2002; Graeff \& Mehlkop, 2003; Wallace \& Latcheva, 2006).

The question is what measures are taken by the respective governments in order to help eliminate corruption incidents. It is interesting the fact that the US government tried to tackle international corruption initially with the enactment of the Law on Foreign Corrupt Practices in 1977, which attributed criminal responsibility to any US citizen or company attempted to bribe civil servants outside the US borders, no matter how the payment was made (FCPA, 2015).

Two decades later, the governments of the 29 OECD members agreed to sign an agreement 
through which they were required to make the cases of overseas corruption punishable. The European Union follows the same practice via its institutions, as well as the Organization of American States that has accepted a series of measures to combat international corruption. In parallel, the World Bank has set stricter conditions for the same reason (Rose-Ackerman, 2007).

The Transparency International movement, which was introduced in 1993, aims to eliminate the problem of corruption worldwide. This organization supports important values such as transparency, solidarity, justice and democracy in order to achieve the elimination of corruption for the future and to enable the states to operate smoothly. It is considered very important that the governments of many countries have expressed a strong interest to cooperate with the Transparency International movement, with constant communication and support to achieve this goal (Transparency International, 2015).

When studying the legal literature there is plethora of definitions regarding the concept of corruption (Deflem, 1995; Gardiner, 2002; Sandgren, 2005). However, despite the fact that this criminal offense is described in various ways since it has many forms, in essence, no definition is considered ideal since it does not completely cover the conditions that characterize corruption, especially its aspect as a criminal issue and as a process to tackle it.

Many policy makers around the world, especially in developed countries, have now realized that the long-term social, economic, human and political cost of corruption worldwide is enormous and that it constitutes a threat to the rule of law, endangering intangible legal rights. As the Criminal Code refers to the legal interests and the great importance of their protection for a well-governed society, the corruption crime should be integrated into the commonly dangerous crimes such as money laundering or the crime of terrorism, in order for the appropriate measures to be taken that would prevent any corruption crime that suppresses the legal interests of any country (Rose-Ackerman, 2013).

This view seems to offer a definitive solution to the question of tackling corruption, with the following conditions:

A) A clear definition of corruption should be determined that would characterize it as an offense exercised by individuals who seek to abuse the position of power they have.

B) The establishment of a classification of existing legal interests which would have common characteristics with classification of the criminal activity factors.

Corruption exists in all countries and all regimes that seem vulnerable when their leaders wish to gain an illegal benefit. The main forms of corruption are bribery, embezzlement, fraud, and extortion (Rose-Ackerman, 2013).

Corruption is essentially the use of public power for private gain. The first obvious place to look is the public sector. The state monopolies on the control of public funds and the preferential access to certain sources of information require strict rules and procedures to ensure fair practices. In the absence of such rules the government is open to a number of corruption forms. The violation of the laws and rules and especially in the intensity this is 
happening today has resulted to the ambiguous interpretation of the concept of corruption.

Corruption could be tackled or at least be reduced significantly through the following three ways (Mitropoulos, 2008):

1) with the promotion of rules that will be harmonized with the particular circumstances of the contemporary social reality

2) through intensive monitoring of the implementation of all existing rules.

3) through the fast and efficient attribution of penalties for violations of the rules without exceptions.

\subsection{Corruption in the Public Sector}

Corruption in modern societies appears as a trend, which is included among the ways one could use to influence government action and acts similar to violence and propaganda (Heidenheimer \& Johnston, 2009). In this direction, corruption refers to the exchange of money or other material goods for preferential treatment on the part of persons in public positions (Grabosky, 2005).

While in the most classical form of political exchange, the government offers and exchanges goods with political consensus in the corruption transaction, where persons in public positions offer privileged access to the state in exchange for money. The corruption phenomena involve at least two parties: the holders of public office who offer privileged access to the state and the citizens who are the recipients and offer money in exchange. According to the political economy approach, the corruption phenomena are generated by the encounter two persons who rely on a cost - benefit calculation and respectively decide that it is to their interest to receive and pay (once or regularly) a sum of money (Rose-Ackerman, 2007).

According to Rose-Ackerman (2007) on the one hand there is a corrupt official who perceives his/her position as a position in the private sector and tries to maximize his/her benefits. The amount of profit depends on the market situation and his/her ability to find the point of maximum profit in the curve of public demand. On the other side there is the customer who may decide that it is to his/her interest to risk any known sanctions and pay the higher costs to make sure that he/she will receive the desired benefits (Masood et al., 2004).

On the basis of the above description of corruption, the theorists of the political economy approach form different types of the individual forms of the cost - benefit relationship, which may be relevant to an intention to participate in a corruption transaction. The possibility of re-election and the position in the public market referred to as variables affecting the operation of corruption of the public official and the structure and effectiveness of the controls as an appreciable cost disaster for both sides.

According to the definition of corruption a number of variables are not taken into account such that (Aidt, 2003):

1. During the illegal transaction the problem of acquaintance and mutual trust occurs for both 
sides. Each of the two sides must have assurances that the other side will not denounce the fact to the justice and moreover that the terms of the "agreement" will be respected.

2. Although the existence of a variable termed "moral cost" is mentioned, in reality it is not taken into account in the development of the individual characteristics that assist the tendency towards corruption. Additionally, understanding corruption as a calculation between the cost and the personal benefit, does not explain the non-corruption under favorable conditions, with very low probability of sanctions. In these cases it may be assumed that the moral cost is high, and thus it has a deterrent effect. Therefore, corruption theories have to face the problem of the conditions that differentiate the moral cost.

3. The corruption networks are more complex than what this approach suggests. The dynamics of a corrupt transaction is complicated by the fact that in the corruption incidents the participation is not just personal. Most often they form part of the operation of larger networks that connect in different ways the public power holders, such as the representatives of the electorate, the civil servants, administrators of public institutions, the party officials, the politicians at local and national level, with those who seek preferential treatment by the state, who can be small and large companies that do business with the public, performers of public works and supply contracts, subcontractors, citizens etc.

Therefore, in order to understand the dynamics of political corruption, these complex transaction networks must be taken into account and be analyzed. The corrupt transaction needs a broad protection network, consisting of several elements that do not directly take part in the ownership of the illegally produced material goods. The corrupt public servant must ensure the main exchange value in relation to the operators and the power to take arbitrary decisions in the co-process of the management of the public affairs (Anderson \& Tverdova, 2003).

\subsection{Corruption in Greece. The Case of Illegal Pensions and Allowances}

This section is the result of primary and secondary research. The primary research was conducted in 60 managers working in the social services of the Social Security Organization (IKA). The sample that was collected was a non-probability sample. It composed of $35 \%$ men and $65 \%$ women. Their average length of service was 29.48 years. In the context of the secondary research the scientific literature was used, such as articles and publications in high traffic Greek newspapers to obtain data on scandals involving the country's insurance agencies that have preoccupied the press and public opinion extensively.

The academic literature on corruption in Greece reflects the assumption that Greek society is prone to corruption, and that the cause is some pathological presence within Greece itself. Illustrative of these trends are the arguments made by Koutsoukis (1993) stating that "Greece is suffering from what relates to the selfish institutionalization of society".

This self-interest refers to the tendency of the members of society to act in a way to promote their own interests at the expense of the public interest. This tendency, in turn, is better understood as a product of social underdevelopment and imbalance, from the low levels of political socialization to the intricacies of the State or the lack of legality, with the shortages 
of material goods in relation to social expectations (Koutsoukis 1993). Through this analysis it is frustrating the fact that the confidence indicators of the Greek society are very low compared with other European countries.

Measuring corruption is a highly complex and continuously changing process with many difficulties. This complexity is due to the lack of a consistent methodology for measuring the phenomenon and also because of the range of the concept of corruption, as well as due to the large "dark" number, namely the number of corruption cases which are not reported and are not officially recorded. The "dark number" of crime which is the difference between the "actual and the obvious crime" is a major problem of crime statistics (Farsedakis, 1996).

Especially in Greece, apart from the issue of latent crime, criminological statistics often show many reliability problems with the methodology followed in the data recording and classification. As supported for Greece, the official statistical information constitutes a problematic source of the criminal phenomenon (Panousis, 2008; Spinelli, 2008). Furthermore, the statistics are inadequate for further analyzes because of their general nature, while they are characterized by structural problems relating to their production processes (Vidali, 2010).

The main problems encountered in the data analysis is mainly the lack of information over time, data variations over time, variability of the primary data recording system and the disparity between the information collected primarily (Iliou, 2009).

The above have resulted in the lack of statistical information on illicit benefits and pensions. This results in the disclosure of the cases that appear only in the press. One example is the fraud case that was set up in the Disability Certification Centers (KEPA) and includes the participation of a corrupt official of the Social Insurance Institution (IKA). With just 44 identified cases of the 253 cases under investigation, it is estimated that the largest pension fund in Greece has lost over $€ 700,000$ funds. The estimate is that the cases concerning illegal benefits and disability pension grants will ultimately exceed 300 and the losses for the Institution will amount to several million Euros. Initially seven people have been arrested, with the brain of the circuit to be a workless 50 year old woman, appearing as an accountant. At least one employee in a key position of the Social Insurance Institution was involved in the circuit, which helped to issue disability certificates. Also five other pensioners were identified, who acted as intermediaries, and an employee in an orthopedics office, who may have been involved in the process. The employee of the Institution delivered the documents to the 50year old accountant who was responsible for their falsification. The documents then seemed to have received the approval of the competent Disability Certification Centers, and therefore the disability pensions and benefits were granted to people who were not entitled these benefits or the percentage of disability was falsely increased (Angelopoulos 2013).

Another case involved a group of people that were captured for obtaining illegal benefits from the Social Insurance Institute and the Freelance Professionals Insurance Organization (OAEE), a case in which civil servants were also involved. According to the Economic Police Department that revealed the fraud, the members of the group falsified documents for a long time in which specific persons were receiving state benefits illegally, while they were also 
setting up fake accidents at the expense of the Social Insurance Institute and the Freelance Professionals Insurance Organization.

In this case, eight (8) people, four men and four women, all Greeks, aged 26-67 years were arrested on March 23, 2015 after the coordinated police operation in various areas of Attica. Among those arrested there was a 53-year-old leading member of the criminal organization, and a 45-year-old OAEE employee. Their co-defendants, who were not arrested because of the passage of this offense, were nine (9) private practitioners, eight (8) doctors of the Social Insurance Institution and twelve (12) nationals, who were charged -per case- for false medical certificates, violation of duty and fraud. More specifically, the months-long and thorough police investigation, launched after a complaint of the OAEE, showed that the 53-year-old leading member of the organization had set up a criminal group, with structured and continuous action, which included the seven (7) persons that were arrested.

The members of the criminal group had distinct and indispensable roles in committing the felonies, with the ultimate purpose to obtain financial gain derived from the simultaneous loss of the Greek state, as responsible for the payment of allowances provided for occupational accidents, welfare benefits, disability pensions, various social benefits (tax exemptions, reduced utilities tariffs etc) and the "fees" they received from their "clients" for processing their cases. Specifically, they prepared the files concerning the issuance of disability pensions, welfare benefits and other social benefits, as well as files of non-existent accidents for people-clients, who were not eligible to receive benefits, upon request to the leading member or other group members. The 45-year-old OAEE employee had a special role in the operation of the criminal organization because of his office and was responsible for the information regarding the insurance coverage of each "client" in order for this to be advantageous.

Note that for every illegal grant of welfare benefit, disability pension or "accident creation", the members of the criminal organization gained the amount of $€ 2,000-5,000$. As verified, the hitherto damage to the Greek state is at least $€ 360,000$, while the threat of damage cannot be determined, since the disability pension or welfare benefit per person was different in each case (ENFIA exemption, exemption from utilities tariffs etc.).

From the investigation of the Economic Police Department so far, 133 individuals have been identified who received welfare benefits and compensation, without meeting the legal requirements, claiming false accidents. Regarding the cases of welfare benefits, disability pensions and social benefits, the investigation showed that the people who did not meet the legal conditions for obtaining such benefits came in contact with the leader and/or the members of the criminal organization, which then communicated the involved doctors who issued, for a fee, the false medical reports in the name of the "clients".

Then, in order to undertake the necessary laboratory tests, which certified the client's alleged health problem, they implement an innovative method. Specifically, they used as partners four nationals, aged 52- to 60-years-old, who actually suffered from health problems and visited private medical centers. In these centers they provided the candidate's personal details, falsely and without being noticed, for the issuance of the welfare allowance and then carried out the required medical tests. The result was to present to the competent health committees 
records of medical tests that were apparently correct and appropriate. With these methodologies, the criminal organization prepared and submitted to the insurers the medical records for disability pensions, welfare benefits, social benefits and non-existent accidents, for a total of 133 individuals (Lampaditi, 2015).

One of the best known cases of corruption in relation to illegal benefits was the one discovered in 2012 in the IKA branch in Attica and specifically in Kallithea. According to case file based on which the employees were convicted, they caused damage to the Greek state of around 11 million Euros. They are accused that between 2003 and 2012, they issued social benefits to 1,300 insured that were not entitled to. Among them, illegal benefits for quintuplet births and maternity benefit to unmarried and childless women, sickness benefits to non-beneficiaries that were going to their work normally, allowances in the name of relatives, friends, and even unsuspecting insured individuals, etc. (Kokkalis, 2015).

\section{Discussion}

As can be seen in the study, the phenomenon of illegal payments in Greece, has considerably expanded and the cases revealed are for huge amounts of money. As a result both the Greek government and taxpayers harmed. An important dimension in the existence of the phenomenon is the participation of public officials in such scams. This further strengthens the opinion of the presence of corruption in the public sector. It should be noted that due to the masking provided by public employees in these situations is not easy the accurate depiction of the phenomenon and constitutes an important limitation to his research. Furthermore, the investigation should be extended to other dimensions such as the identification of the causes and factors that motivate public officials and citizens to participate in corruption phenomena.

\section{Conclusion}

The phenomenon of corruption of the public officials regarding illegal pensions and benefits in Greece has a wide range and has not been examined in depth. Most cases were discovered following a complaint that led to the further investigation.

The fact is that, especially in this area, the civil servants are not the only responsible since these phenomena have arisen from the cooperation between public officials and citizens who agree to take these illegal benefits and pensions and thus contribute to the development of corruption.

The phenomenon of illegal benefits and pensions in Greece is an indisputable case of cooperation between citizens and public officials, aimed at the illegal collection of money amply demonstrating the social acceptance and establishment of corruption.

This demonstrates the political dimension and base of corruption. The consequences of corruption in the public space, especially when generalized, are devastating for the institutions, the economy and social life. Legality is abolished, institutions undermined, human rights are scorned, intermediaries penetrate the government agencies, politics is discredited and the bribes and unfair favors become customary practices. The vileness and coercive interventions rule. Moreover, the private economic activity is challenged by 
uncertainty, underground economy, clientelism, unfair pressure or extortion and maladministration. At the same time, government revenues decline and the national economy is threatened by the squandering of the public wealth since large amounts change hands illegally. Finally, individual virtue and personal morality are devalued, the cunning, the opportunists and exploiters are considered smart and successful, while law-abiding and honest people are deemed incompetent and naive. This reversal of criteria and values leads to social corrosion.

To combat corruption it is necessary to attempt a decisive campaign against corruption in the public space and to inform the public. In order for everybody to realize the seriousness and extent of the problem, the risks should be identified both for the economy and trade, and for human rights and the institutions that support legitimacy and democracy. The effort to inform the public should be carried out by government circulars and prosecutors to be sent to all public sector services, economic, urban, social security, law enforcement agencies, ministries, etc., with publicity through the press and the media, and the sincere and unequivocal declaration that corruption phenomena will be systematically combated, without any ex post facto, and an invitation to the authorities and citizens not to tolerate and to report such phenomena.

\section{References}

Acemoglu, D., \& Verdier, T. (2000). The choice between market failures and corruption. American Economic Review, 90(1), 194-211. http://www.jstor.org/stable/117287

Aidt, T. S. (2003). Economic analysis of corruption: a survey. The Economic Journal, 113(491), F632-F652. https://doi.org/10.1046/j.0013-0133.2003.00171.x

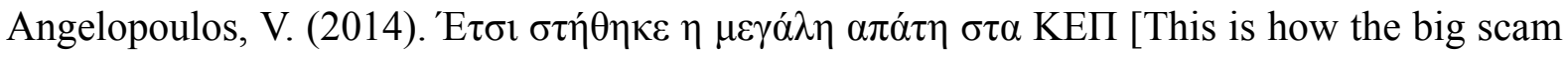
was set up in the KEPA]. Retrieved on February 15, 2017, from http://www.dikaiologitika.gr/eidhseis/asfalish/45911/ika- etsi-stithike-i-megali-apati-sta-kepa

Anderson, C. J., \& Tverdova, Y. V. (2003). Corruption, political allegiances, and attitudes toward government in contemporary democracies. American Journal of Political Science, 47(1), 91-109. https://doi.org/10.1111/1540-5907.00007

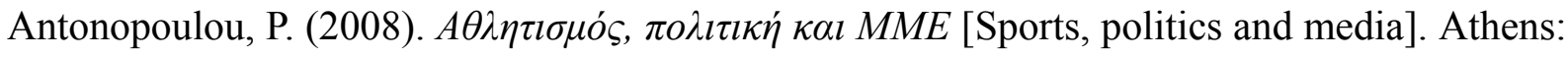
Drakopoulou.

Bardhan, P. (1997). Corruption and development: a review of issues. Journal of Economic Literature, 35(3), 1320-1346. http://www.jstor.org/stable/2729979

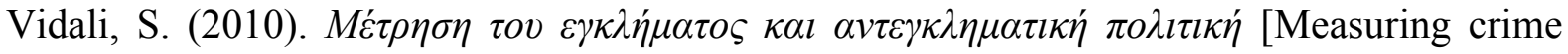
and anti-criminal policy]. Athens, Attikis: Sakkoulas.

Deflem, M. (1995). Corruption, law, and justice: A conceptual clarification. Journal of Criminal Justice, 23(3), 243-258. https://doi.org/10.1016/0047-2352(95)00018-L

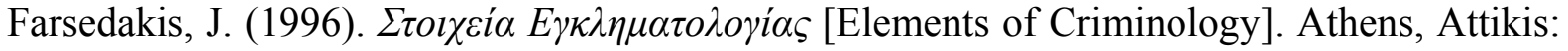
Law Library). 
Gardiner, J. A. (2002). Defining corruption. In A. J. Heidenheimer, \& M. Johnston (Eds.), Political Corruption: Concepts and Contexts (pp. 25-40). New Brunswick, NJ: Transaction Publishers.

Grabosky, P. N. (2005). Controlling fraud, waste and abuse in the public sector. Australian Institute of Criminology, Australia.

Graeff, P., \& Mehlkop, G. (2003). The impact of economic freedom on corruption: different patterns for rich and poor countries. European Journal of Political Economy, 19(3), 605-620. https://doi.org/10.1016/S0176-2680(03)00015-6

FCPA (2015). Foreign Corrupt Practices Act. Retrieved on February 10, 2016, from http://www.justice.gov/criminal-fraud/foreign-corrupt-practices-act

Heidenheimer, A. J., \& Johnston, M. (2009). Political Corruption. New Jersey: Transaction Publishers.

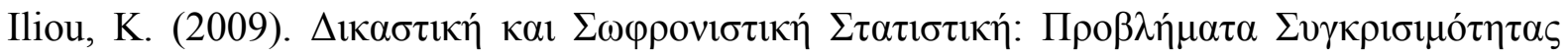

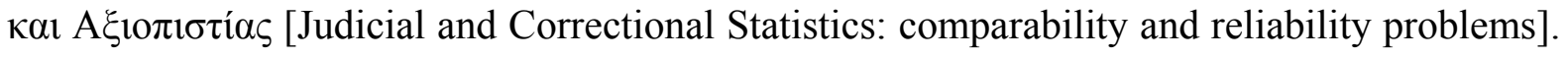
Review of Social Research, 129, 75-100.

Hwang, M., \& Lim, K. (2013). The judicial scrutiny of arbitral awards in setting aside and enforcement proceedings involving issues of corruption. Transnational Dispute Management, 10(3). www.transnational-dispute-management.com

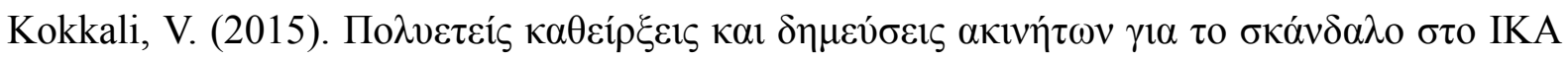
$\mathrm{K} \alpha \lambda \lambda_{1} \theta \varepsilon \dot{\varepsilon} \alpha \varsigma$ [Perennial sentences and confiscation of property for the scandal of IKA in Kallithea]. Retrieved on February, 15, 2017, from www.protothema.gr/greece/article/462945/polueteis-katheirxeis-kai-dimeuseis-akiniton-gia-t o-skandalo-sto-ika-kallitheas/urnal

Koutsoukis, K. (1993). The good the bad and the ugly in society: the self-interest institution of society as a source of corruption (the case of Greece)]. Paper presented at the Third International Conference on Ethics in Public Service.

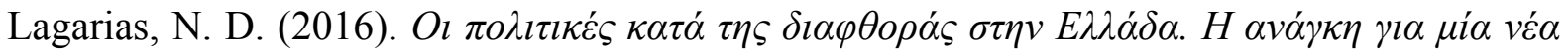
$\pi \rho о \sigma \dot{\gamma} \gamma \gamma l \sigma \eta$ [Policies against corruption in Greece. The need for a new approach]. Athens, Attikis: N. D. Lagarias.

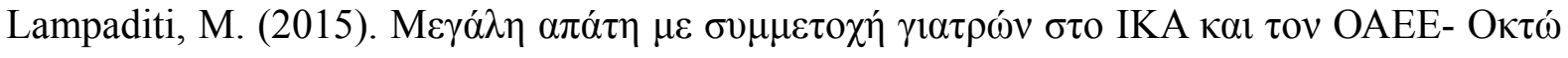
$\sigma 0 \lambda \lambda \eta \dot{\psi} \psi \varepsilon 1 \varsigma$ [Big scam involving doctors in IKA and OAEE - Eight arrests]. Retrieved on February, 15, 2017, from http://www.protothema.gr/greece/article/462848/megali-apati-me-summetohi-giatron-sto-ikakai-ton-oaee-okto-sullipseis-/

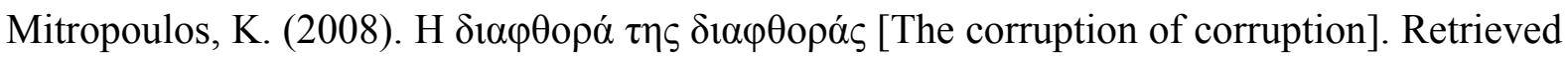
on December, 15, 2016, from http://www.tovima.gr/relatedarticles/article/?aid=9157

Mo, P. H. (2001). Corruption and economic growth. Journal of Comparative Economics, 29(1), 
66-79. https://doi.org/10.1006/jcec.2000.1703

Montinola, G. R., \& Jackman, R. W. (2002). Sources of corruption: A cross-country study. British Journal of Political Science, 32(01), 147-170. https://doi.org/10.1017/S0007123402000066

Morris, S. D. (2011). Forms of corruption. DICE Report, 9(2), 10-14.

Osipian, A. L. (2010). Corruption in the politicized university: Lessons for Ukraine's 2010 presidential elections. Innovation: The European Journal of Social Science Research, 23(2), 101-114. https://doi.org/10.1080/13511610.2010.512440

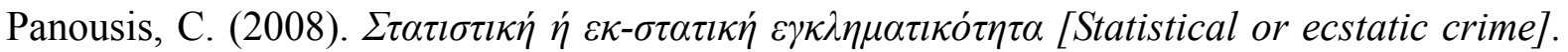
Athens, Attikis: Sakkoulas.

Rose-Ackerman, S. (Ed.). (2007). International handbook on the economics of corruption. Edward Elgar Publishing.

Rose-Ackerman, S. (2013). Corruption: A study in political economy. Academic Press.

Sandgren, C. (2005). Combating corruption: the misunderstood role of law. The International Lawyer, 39(3) 717-731. http://www.jstor.org/stable/40707811

Seligson, M. A. (2002). The impact of corruption on regime legitimacy: A comparative study of four Latin American countries. The Journal of Politics, 64(2), 408-433. http://www.jstor.org/stable/2691854?origin=JSTOR-pdf

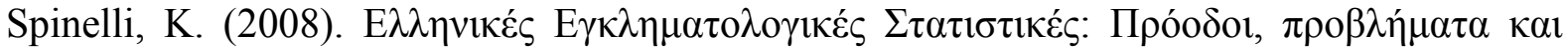

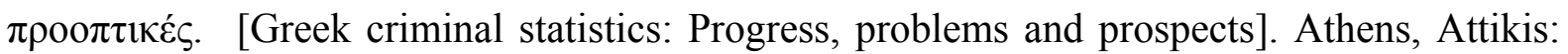
Sakkoulas.

Tanzi, V. (1998). Government role and the efficiency of policy instruments. In P. B. Sorensen (Ed.), Public finance in a changing world (pp. 51-69). Palgrave Macmillan.

Treisman, D. (2000). The causes of corruption: a cross-national study. Journal of Public Economics, 76(3), 399-457. https://doi.org/10.1016/S0047-2727(99)00092-4

Wallace, C., \& Latcheva, R. (2006). Economic transformation outside the law: corruption, trust in public institutions and the informal economy in transition countries of Central and Eastern Europe. Europe-Asia Studies, 58(1), https://doi.org/10.1080/09668130500401707

\section{Copyrights}

Copyright for this article is retained by the author(s), with first publication rights granted to the journal.

This is an open-access article distributed under the terms and conditions of the Creative Commons Attribution license (http://creativecommons.org/licenses/by/4.0/) 